\begin{tabular}{|l|l|}
\hline JANHSS Journal of Animal Husbandry Science \\
\hline
\end{tabular}

\title{
RISIKO KONTAMINASI LOGAM BERAT TIMBAL DAN CADMIUM PADA DAGING DAN HATI SAPI YANG DIGEMBALAKAN DI AREAL BEKAS LAHAN PERTANIAN KECAMATAN WASILE TIMUR
}

\author{
(Heavy Metal Contamination Risk of Lead and Cadmium Meat and eart \\ on Cattle Grazing Area Former District Agricultural Land East Wasile)
}

\author{
Sri Lestari \\ ${ }^{1}$ Dosen Program Studi Peternakan Fakultas Pertanian \\ Universitas Khairun, Ternate \\ Email:tari.kiss@yahoo.co.id
}

\begin{abstract}
Abstrak
Bekas lahan pertanian merupakan salah satu lahan dimana masyarakat mengelola untuk menggembalakan ternaknya dalam memanfaatkan pakan hijauan yang tumbuh dan berkembang. Hal ini memicu kekhawatiran bahwa bekas lahan pertanian sudah tercemar oleh logam berat akibat penggunakan pupuk-pupuk yang mengandung bahan kimia. Tujuan dari penelitian ini melihat risiko kontaminasi logam berat timbal $(\mathrm{Pb})$ dan cadmium $(\mathrm{Cd})$ yang terjadi pada daging dan hati sapi yang digembalakan di lahan bekas pertanian. Metode yang digunakan dalam penelitian ini menggunakan metode SSA (Spektometri Serapa Atom) untuk mendeteksi keberadaan logam berat pada hati dan daging sapi yang digembalakan di bekas lahan pertanian yang terdiri dari 3 ulangan. Hasil penelitian menunjukan bahwa kandungan logam berat $\mathrm{Pb}$ pada hati pada ulangan HTs1-HTs3 yaitu sebesar 1,025-1,352 ppm dan pada daging sapi pada ulangan HTs1-HTs3 yaitu sebesar 1,01-1,005ppm. Maka hati dan daging sapi yang digembalakan di bekas lahan pertanian melebihi ambang batas yang telah ditetapkan SNI maupun WHO. Sedangkan logam berat $\mathrm{Cd}$ masih berada diambang batas yang telah diisyaraatkan. Sehingga perlu diwaspadai dampaknya bagi kesehatan manusia yang mengkonsumsinya.
\end{abstract}

Kata kunci: Logam berat, sapi potong, dan bekas lahan pertanian

\begin{abstract}
Former agricultural land is one of the areas where, people manage to graze their livestock in the use of forage feed that grows and develops. This has sparked concern that the former agricultural land has been contaminated by heavy metals due to the use of fertilizers containing chemicals. The purpose of this study looked at the risk of contamination of heavy metals lead $(\mathrm{Pb})$ and cadmium $(C d)$ occurring in cattle meat and liver grazing on former agricultural land. The method used in this research is using SSA (Serapa Atomic Spectometry) method to detect the presence of heavy metals in liver and beef grazed in the former farmland consisting of 3 replications. The
\end{abstract}


results showed that the heavy metal content of $\mathrm{Pb}$ in the liver on HTs1-HTs 3 replication of 1.025$1.352 \mathrm{ppm}$ and in beef on HTs1-HTs3 replication of 1.01-1.005ppm. So the liver and beef grazed in the former agricultural land exceed the threshold set by both SNI and WHO. While heavy metal $C d$ is still on the boundary that has been dikisyaraatkan. So need to watch out for the impact on human health that consume them.

Keywords: Heavy metals, beef cattle, and former agricultural land

\section{Pendahuluan}

Rumput yang hidup dan tumbuh dibekas area lahan pertanian memberikan peluang bagi para peternak memanfaatkan hijaunya untuk menggembalakan ternaknya. Namun dilain pihak kekhawatiran yang muncul kemungkinan terjadinya akumulasi logam berat pada tanah, rumput dan sumber air yang berdampak akumulasi logam berat pada hewan yang hidup di area bekas lahan pertanian.Gunawan (2015) menemukan kadar $\mathrm{Pb}$ berlebihan pada air di kawasan pertanian.

Salah satu aspek jalur masuknya xenobiotik (senyawa asing) yang dapat menciderai kesehatan ternak maupun manusia melalui asupan substansi toksik yang bersumber dari makanan yang dikonsumsi. Palar (2004), menyebutkan bahwa logam berat masuk ke dalam tubuh makhluk hidup melalui rantai makanan, pernapasan atau penetrasi melalui kulit. Daging dan produk daging merupakan salah satu bahan pangan yang memiliki banyak penikmat, namun di dalamnya mungkin membawa sejumlah substansi toksik. Walaupun jumlahnya cukup kecil di dalam daging, namun pada bagian tertentu pada tubuh ternak yang juga sering dikonsumsi misalnya pada organ hati dan ginjal, sering menunjukkan konsentrasi substansi toksik yang cukup tinggi (Khalafalla et al. ,2011).

Keamanan pangan ini seringkali disepelekan oleh masyarakat karena tidak semua kasus pencemaran keamanan pangan memberikan respon negatif bagi tubuh yang dapat langsung diamati satu atau dua hari setelah mengkonsumsinya. Bahan kimia tambahan maupun bahan kimia asing misalnya logam berat yang terkonsumsi tidak menunjukkan respon buruk bagi kesehatan yang dapat teramati pada selang waktu satu atau dua hari setelah konsumsi, namun gangguan kesehatan yang diakibatkan akan tampak dalam jangka waktu yang cukup panjang setelah mengkonsumsinya. Logam berat merupakan senyawa asing dapat masuk melalui makanan kemudian terakumulasi di dalam tubuh dalam kurun waktu tertentu dan menimbulkan gangguan kesehatan.

Pengembalaan ternak khususnya ternak sapi potong di area bekas lahan pertanian dengan memanfaatkan pakan hijauan berpotensi mencemari daging dan organ tubuh sapi lainnya yang apabila hasil ternak tersebut dikonsumsi oleh manusia dapat menyebabkan akumulasi logam berat dalam tubuh manusia. Logam berat yang terakumulasi dalam tubuh akan menghalangi kerja biomolekul esensial untuk proses-proses biologis, menggantikan ion-ion logam esensial yang terdapat dalam biomolekul dan memperbanyakperubahan bentuk dari gugus aktif yang dimiliki oleh biomolekul yang mengakibatkan malfungsi sistem metabolisme tubuh. Oleh karena itu, perlu dilakukan evaluasi tingkat kontaminasi logam berat serta mengkaji potensi risiko yang ditimbulkan jika mengkonsumsi daging sapi yang dipelihara di areabekas lahan pertanian. 


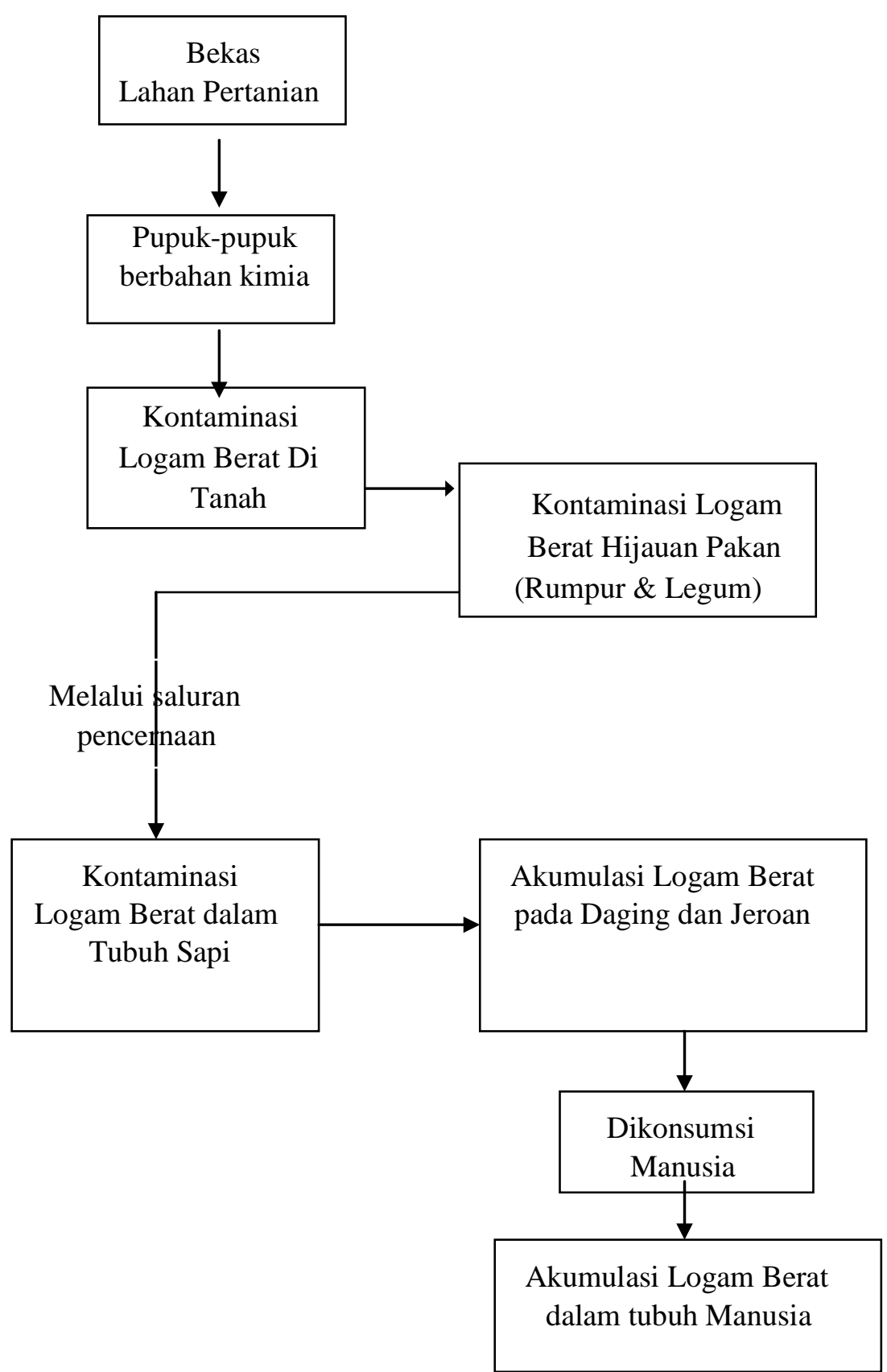

Gambar 1. Alur kerangka pikir

\section{Tujuan}

Tujuan umum penelitian ini adalah melihat risiko kontaminasi logam berat timbal $(\mathrm{Pb})$ dan cadmium $(\mathrm{Cd})$ yang terjadi pada daging dan hati sapi yang digembalakan di lahan bekas pertanian.

\section{Manfaat Penelitian}

Manfaat dari penelitian ini diharapkan dapat memberikan sumbangan yang berarti bagi pemerintah daerah dalam menyusun kebijakan pembangunan peternakan dan mengungkap 
beberapa informasi kemungkinan risiko bahaya konsumsi hati dan daging sapi yang digembalakan pada bekas lahan pertanian yang merupakan sumbangan ilmiah tentang sumbersumber terjadinya residu logam berat akibat aktifitas pertanian.

\section{$2 \quad$ Metodologi}

\subsection{Waktu dan Tempat}

Penelitian ini dilakukan di sekitar lahan bekas pertanian di Kecamatan Wasile Halmahera Timur dan Balai Besar Teknik Kesehatan Lingkungan dan Pemberantasan Penyakit Menular (BPTKLPPM) Yogyakarta. Pada bulan Juni sampai November 2016

\subsection{Bahan dan Metoda Penelitian}

\section{Bahan dan alat Penelitian}

Bahan yang digunakan dalam penelitian ini adalah daging dan hati sapi yangberumur $\geq 2$ tahun diperoleh dari Tempat Potong Hewan (TPH) yang dihidupnya digembalakan di lahan bekas pertanian, aquades, asam nitrat (HNO3), larutan standar logam $\mathrm{Pb}$, dan $\mathrm{Cd}$. Alat yang digunakan adalah kamera, daftar pertanyaan (questioneraire), Coolbox, dan SSA (Shimadzu AA-7000) (Spektrometri Serapan Atom) untuk analisa logam berat $\mathrm{Pb}$, dan $\mathrm{Cd}$, timbangan analitik, gelas piala $250 \mathrm{ml}$, pipet ukur, labu ukur $100 \mathrm{~mL}$, corong, erlenmeyer, pemanas listrik, kertas saring whatman dan labu semprot.

\section{Metode Penelitian (Tahapan Penelitian)}

\section{Pengumpulan data}

Pengumpulan data ini dilakukan dengan cara pengamatan langsung di lapangan yaitu peternak yang berada di lahan bekas pertanian Kecamatan Wasile. Pemilihan lokasi penelitian dilakukan secara sengaja (purposive random sampling) yaitu lokasi penelitian merupakan daerah sekitar lahan bekas pertanian sering digunakan oleh peternak untuk menggembalakan ternaknya.

\section{Pengambilan Sampel} (TPH).

Pengambilan sampel penelitian ini adalah produk peternakan dari Tempat Potong Hewan

1. Sampel hati pada ternak sapi potong diambil sebanyak 300 gram terdiri 3 ulangan. Kemudian sampel dianalisis di laboratorium menggunakan metode Spektrometri Serapan Atom (SSA).

2. Sampel daging diambil dari bagian paha belakang sebanyak 300 gram dengan setiap sampel terdiri 3 ulangan di lahan bekas pertanian Kecamatan Wasile Timur kemudian dianalisis logam berat dengan menggunakan Spektrometri Serapan Atom (SSA).

\section{Preparasi Sampel Hati dan Daging untuk Pb, Cd (SNI 2009)}

Analisis sampel hati, dan daging sapi potong dengan cara dimasukkan 15 gram sampel uji ke dalam gelas piala, lalu ditambahkan pereaksi HNO3 65\% sebanyak $10 \mathrm{~mL}$ dan asam perkhlorat $68 \%$ sebanyak $2 \mathrm{~mL}$ hingga seluruh sampel terendam. Dipanaskan di pemanas diatas hotplate sampai larut kurang lebih 4-6 jam sampai sampel uji larut seutuhnya dan larutan berwarna kuning jernih. Kemudian ditambahkan aquades hingga volume $50 \mathrm{ml}$ dan dimasukkan ke dalam labu ukur melalui kertas saring untuk menyaring lemak yang ada dan siap diinjeksi menggunakan Spektrometri Serapan Atom (SSA). 


\section{Peubah yang Diamati}

Peubah yang diamati dalam penelitian ini yaitu menganalisis logam berat pada hati dan daging sapi potong yang digembalakan di sekitar lahan bekas pertanian

\section{Analisis Data}

Analisis data cemaran logam berat pada produk pada hati dan daging sapi, dalam penelitian ini menggunakan uji GLM (General Linear Model). Sedangkan membandingkan kandungan logam berat pada setiap ulanganyang berbeda dilakukan dengan mengunakan Uji-T.

di mana :

$$
t=\frac{\bar{x}_{1}-\bar{x}_{2}}{\sqrt{s^{2}\left[\frac{1}{n_{1}}+\frac{1}{n_{2}}\right]}}
$$

$$
\begin{aligned}
& \mathrm{n}_{\mathrm{i}}=\text { jumlah pengamatan } \\
& \bar{x}_{\mathrm{i}}=\text { rataan sampel } \\
& \mathrm{s}_{\mathrm{i}}=\text { standar deviasi yang diperkirakan }
\end{aligned}
$$

dengan :

$$
s^{2}=\frac{\left(s_{1}-1\right) S_{1}^{2}-\left(s_{2}-1\right) S_{1}^{2}}{n_{1}+n_{2}-2}
$$

\section{Hasil dan Pembahasan}

\section{Cemaran Logam Berat pada Daging dan Jeroan Sapi Potong}

Kontaminasi daging oleh logam berat dapat menjadi ancaman yang serius karena beberapa logam berat dapat bersifat toksik pada level tertentu. Logam berat dapat mengalami bioakumulasi dan biomagnifikasi sepanjang rantai makanan (Demirezen dan Uruc 2006). Kandungan logam berat pada daging danorgan ternak sapi potong yang digembalakan dilahan bekas pertanianini sering kali terjadinya cemaran akibat dari aktivitas manusia, hal ini terlihat pada tabel-tabel dibawah ini.

Tabel 1. Rata-rata kandungan logam berat pada hati sapi yang digembalakan dibekas lahan pertanian Kecamatan Wasile Kabupaten Halmahera Timur

\begin{tabular}{llllll}
\hline \multirow{2}{*}{ Logam Berat } & Ulangan & & & \multicolumn{2}{c}{ Standar MRL } \\
\cline { 2 - 6 } & HTs1 & HTs2 & HTs3 & SNI $^{1}$ & WHO $^{2}$ \\
\hline $\mathrm{Pb}(\mathrm{ppm})$ & $1,025 \mathrm{a}$ & $1,352 \mathrm{~b}$ & $1,087 \mathrm{c}$ & 1,00 & 0,10 \\
$\mathrm{Cd}(\mathrm{ppm})$ & 0,036 & 0,024 & 0,017 & 0,050 & $0.15-0.50$ \\
\hline
\end{tabular}

Nilai pada baris yang sama diikuti dengan huruf yang berbeda menunjukan perbedaan nyata $(\mathrm{P}<0.05), \mathrm{HTs}=$ Hasil Ternak Sapi 1.Standar Nasional Indonesia 7378: 2009, 2.WHO (1996); Pb = timbal; $\mathrm{Cd}=$ cadmium; MRL (Maximum Residue Limit).

Kontaminasi daging oleh logam berat dapat menjadi ancaman yang serius karena beberapa logam berat dapat bersifat toksik pada level tertentu. Logam berat dapat mengalami bioakumulasi dan biomagnifikasi sepanjang rantai makanan (Demirezen dan Uruc 2006). Kandungan logam berat pada organ hati dari ternak sapi potong yang digembalakan di area lahan bekas pertanian dapat dilihat pada hasil Tabel 1 . 
Hasil penelitian menunjukkan bahwa cemaran logam $\mathrm{Pb}$, pada perlakuan HTs1-HTs3 di hati sapi potong yang digembalakan dilahan bekas pertanian jika mengacu pada standar SNI maupun standar dari WHO menunjukan bahwa logam berat $\mathrm{Pb}$ melebihi ambang batas standar yang telah disyaratkan. Hal ini karena peran dari organ hati sebagai salah satu organ untuk detoksifikasi racun di dalam tubuh organisme. Stansley et al. (1991) menyatakan bahwa akumulasi $\mathrm{Pb}$ dapat terjadi di dalam organ-organ seperti hati, ginjal dan target jaringan termasuk otot. Level $\mathrm{Pb}$ dalam otot biasanya jauh lebih rendah daripada hati dan ginjal. Menurut Peterle (1991) hati dan ginjal merupakan organ tempat logam berat mengalami proses metabolisme dan proses ekskresi. Hal serupa dikatakan Hodgson dan Levi (1997) hati sebagai salah satu muara terakumulasi senyawa racun diantaranya logam berat karena seluruh hasil pencernaan akan diabsorpsi ke dalam hati melalui vena portal hepatica, sehingga hati merupakan organ pertama yang berhubungan dan melakukan metabolisme terhadap racun yang terserap dalam saluran pencernaan. Hati memiliki enzim detoksifikasi yang mampu melakukan biotransformasi terhadap bahan-bahan toksik, dan banyak reaksi oksidasi yang dapat meningkatkan metabolisme sehingga mengakibatkan hati lebih mudah menyerap bahan-bahan toksik. Sedangkan logam berat Cd pada hati di semua perlakuan masih berada diambang batas yang diisyaratkan.

Tabel 2. Rata-rata kandungan logam berat pada daging sapi yang digembalakan di lahan bekas pertanian Kecamatan Wasile Kabupaten Halmahera Timur

Nilai pada baris yang sama diikuti dengan huruf yang berbeda menunjukan perbedaan nyata $(\mathrm{P}<0.05)$, HTs $=$ Hasil Ternak Sapi 1.Standar Nasional Indonesia 7378: 2009, 2. WHO (1996); $\mathrm{Pb}=$ timbal; $\mathrm{Cd}=$ cadmium; MRL (Maximum Residue Limit).

\begin{tabular}{llllll}
\hline \multirow{2}{*}{ Logam Berat } & \multicolumn{2}{l}{ Ulangan } & \multicolumn{3}{l}{ Standar MRL } \\
\cline { 2 - 6 } & HTs1 & HTs2 & HT3 & SNI $^{1}$ & WHO $^{2}$ \\
\hline $\mathrm{Pb}(\mathrm{ppm})$ & $1,004 \mathrm{a}$ & $1,005 \mathrm{a}$ & $1,01 \mathrm{~b}$ & 1,00 & 0,10 \\
$\mathrm{Cd}(\mathrm{ppm})$ & 0,012 & 0,012 & 0,012 & 0,050 & $0.15-0.50$ \\
\hline
\end{tabular}

Hasil analisis $\mathrm{Pb}$ (Tabel 2) yang dilakukan pada daging sapi yang dipelihara di bekas lahan pertanian melebihi ambang batas yang di tetapkan oleh BSN (2009). Hal ini sejalan dengan standar yang ditetapkan WHO maka daging sapi yang dipelihara di bekas lahan pertanian tidak layak dikonsumsi oleh masyarakat karena melebihi ambang batas. Sedangakan pada logam berat Cd masih berada diambang batas maksimum.

Standar Nasional Indonesia (2009) mempersyaratkan batas maksimum $1.0 \mathrm{mg} / \mathrm{kg}$ timbal $(\mathrm{Pb})$ dalam daging dan produk daging, namun WHO, 1996 menetapkan standar yang lebih ketat, yaitu sebesar $0.10 \mathrm{mg} / \mathrm{kg}$ untuk daging dan $0.50 \mathrm{mg} / \mathrm{kg}$ untuk organ sapi yang dapat dikonsumsi. Asupan mingguan untuk orang dewasa yang ditoleransi sebesar $0.005 \mathrm{mg} / \mathrm{kg}$ dengan berat badan $70 \mathrm{~kg}$. Tempat penyerapan $\mathrm{Pb}$ pertama kali melalui plasma dan membran jaringan lunak, selanjutnya didistribusikan ke bagian-bagian dimana kalsium memegang peranan penting. Timbal dapat masuk ke dalam tubuh melalui pernapasan dan makanan. Konsumsi timbal dalam jumlah banyak secara langsung menyebabkan kerusakan jaringan, termasuk kerusakan jaringan mukosa. Sistem yang paling sensitif adalah sistem sintesis jaringan darah (hematopoietik) sehingga biosintesis haema terganggu. Semua sel-sel yang sedang aktif berkembang sensitif terhadap timbal. Timbal juga dapat merusak syaraf (SNI 2009). Akumulasi Pb pada tanah dan air permukaan tergantung pada berbagai faktor seperti $\mathrm{pH}$, komposisi mineral atau jumlah dan jenis bahan organik. orang dapat terpapar $\mathrm{Pb}$ melalui makanan, air, udara, tanah dan debu, namun makanan merupan sumber utama. Di dalam tubuh, timbal diperlukan seperti halnya kalsium.

Masyarakat yang mengkonsumsi bahan pangan berupa daging yang tercemar kandungan logam berat $\mathrm{Pb}$ dalam jumlah yang banyak maka dapat berpengaruh terhadap tubuh karena 
menghambat kerja enzim dan menyebabkan kerusakan sel. Sifat-sifat membran dari dinding sel akan rusak karena pengikatan dengan timbal sehingga aktivitas sel dapat terganggu. Menurut Widaningrum et al. (2007) kondisi yang akut dapat menyebabkan kerusakan perut dan usus, gagal kardiovaskular (jantung dan pembuluhnya), dan gagal ginjal akut yang dapat menyebabkan kematian.

\section{$4 \quad$ Kesimpulan}

Dari hasil penelitian dapat diperoleh yang digembalakan dibekas lahan pertanian telah terjadi cemaran kimia kesimpulan bahwa ternak yang berasal dari penggunaan bahan-bahan kima yang telah mencemari lingkungan. Kandungan residu logam berat $\mathrm{Pb}$ melebihi ambang batas yang telah ditetapkan SNI maupun WHO. Maka perlu lebih diwaspadai dampaknya terhadap kesehatan manusia yang mengkonsumsinya, sedangkan logam $\mathrm{Cd}$ masih berada di ambang batas yang diisyaratkan.

\section{$5 \quad$ Daftar Pustaka}

Demirezen, O and K. Uruc, 2006. Comparative Study of Trace Elements in Certain Fish, Meat and Meat Products. Food Chem 32:215-222.

Gunawan., 2015. Kualitas Ternak Sapi Potong Sekitar Tambang Nikel Kabupaten Halmahera Timur. [tesis] Institut Pertanian Bogor. IPB Bogor.

Hodgson E, Levi PE. 1997. A Textbook of Modern Toxicology. 2nd Edition. Mc Graw Hill. Singapore.

Khalafalla FA, Ali FH, Schwagele F and Abd-El-Wahab MA. 2011. Heavy Metal Residues in Beef Carcassaes in Beni-Suef Abbatoir, Egypt. Vet Italy. 47(3):351-361.

Palar. Heryando., 2004. Pencemaran dan Toksikologi Logam Berat. Rineka cipta. p. 78-86. Jakarta.

Peterle TJ. 1991. Wildlife Toxicology. Van Nostrand Reinhold. New York.

Stansley W, Roscoe DE, Hazen RE. 1991. Cadmium Contamination of Deer Livers in New Jersey: Human health risk assessment Sci Total Environ. 107:71-78.

[SNI] Standar Nasional Indonesia. 2009. Batas Maksimum Cemaran Logam Berat dalam Pangan. SNI 7387:2009. ICS 67.220.20

Widaningrum, Miskiyah, Suismono. 2007. Bahaya Kontaminasi Logam Berat dalam Sayuran dan Alternatif Pencegahan Cemarannya. BTPP. 3:16-27. 